\title{
A mikrobiológiai vizsgálatok szerepe a peritonsillaris tályog kezelésében hat év anyagának retrospektív elemzése alapján
}

\author{
Erdélyi Eszter dr. ${ }^{1}$ - Ambrus Andrea dr. ${ }^{1}$ - Szabó Linda dr. ${ }^{1}$ \\ Kiricsi Ágnes dr. ${ }^{1}$ - Nagy Erzsébet dr. ${ }^{2}$ - Rovó László dr. ${ }^{1}$ - Bella Zsolt dr. ${ }^{1}$ \\ ${ }^{1}$ Szegedi Tudományegyetem, Általános Orvostudományi Kar, \\ Fül-Orr-Gégészeti és Fej-Nyaksebészeti Klinika, Szeged \\ ${ }^{2}$ Szegedi Tudományegyetem, Általános Orvostudományi Kar, Klinikai Mikrobiológiai Diagnosztikai Intézet, \\ Szeged
}

\begin{abstract}
Bevezetés és célkitüzés: A peritonsillaris tályog a leggyakoribb mély nyaki infekció. Olyan fül-orr-gégészeti kórkép, amely megfelelő kezelés nélkül életveszélyes szövődményekkel járhat. Döntő jelentőségű az empirikus antibiotikumválasztás, melyhez ismerni kell a leggyakoribb kórokozókat és a várható rezisztenciát.

Módszerek: A 2012 és 2017 között peritonsillaris tályog miatt kezelt esetek retrospektív feldolgozását végeztük. Öszszesítettük a sebészi beavatkozás során vett minták aerob és anaerob irányú tenyésztési eredményeit, valamint az empirikusan választott antibiotikumokat. A rutinszerü mikrobiológiai tenyésztés alapján meghatároztuk a leggyakoribb kórokozókat. Az adatokat nemzetközi felmérések eredményeivel hasonlítottuk össze.

Eredmények: A vizsgált 6 év során 217 esetben kezeltünk peritonsillaris tályogos beteget. A tenyésztési eredményeket csak 146 esetben tudtuk elemezni. Ebből 47 esetben került sor Fusobacterium species (ebből 25 esetben Fusobacterium necrophorum), 31 esetben Actinomyces species és 29 esetben Streptococcus pyogenes izolálására. Az esetek kétharmadában vegyes aerob/anaerob baktériumflórát izolált a laboratórium.

Következtetés: A tályogok kezelésében önmagában a sebészi beavatkozás - az anaerob környezet megszüntetésével jelentős klinikai javulást eredményez. A jól választott antibiotikum meggyorsíthatja a lefolyást, és csökkentheti az esetleges szövődményeket. Nagy jelentősége van a megfelelő mikrobiológiai mintavételnek, nem vagy nehezen gyógyuló esetekben ez teremtheti meg a célzott antibiotikumterápiára történő váltás lehetőségét. Felmérésünk alapján a peritonsillaris tályogok jelentős részét vegyes baktériumflóra okozza, így a szájüregi anaerob baktériumokra is ható amoxicillin-klavulánsav vagy antibiotikum kombinációjának (2. vagy 3. generációs cefalosporinok kombinálva klindamicinnel vagy metronidazollal) alkalmazása javasolt mint empirikus antibiotikumterápia.
\end{abstract}

Orv Hetil. 2020; 161(44): 1877-1883.

Kulcsszavak: peritonsillaris tályog, mikrobiológiai mintavétel, aerob/anaerob infekció

\section{The role of microbiological examination in treating peritonsillar abscess based on the retrospective analysis of data from six years}

\footnotetext{
Introduction and objective: Peritonsillar abscess is the most common deep neck infection. Without adequate treatment, this otolaryngological disease pattern can cause life-threatening complications. The empirical choice of antibiotics is crucial which requires knowledge of the most common pathogens and the potential resistance.

Methods: A retrospective analysis of cases treated for peritonsillar abscess was performed between 2012 and 2017 . We summarized the aerobic and anaerobic culture results of the surgical samples and the empirically selected antibiotics. The most common pathogens were determined via routine microbiological culture tests. We compared our data with the results of international studies.

Results: During the 6-year study at our Clinic, 217 patients with peritonsillar abscess were treated. The microbiological tests were available for analysis in only 146 cases. In 47 cases, Fusobacterium species (including 25 cases with Fusobacterium necrophorum), in 31 cases Actinomyces species and in 29 cases Streptococcus pyogenes were isolated. In $2 / 3$ of the patients, polymicrobial infection was detected.
} 
Conclusion: In the treatment of peritonsillar abscesses, surgical intervention can result in clinical improvement because of the elimination of the anaerobic milieu. A well-chosen antibiotic can accelerate the healing process and reduce the complication rate. Proper microbiological sampling is of great importance, and in cases of non-recovery or poor recovery, this may create the opportunity to switch for targeted antibiotic therapy. The results of this study show that polymicrobial flora is very important for the development of the peritonsillar abscess, thus the recommended antibiotic therapy is amoxicillin-clavulanic acid or $2 \mathrm{nd} / 3 \mathrm{rd}$ generation cefalosporin combined with metronidazol or clindamycin.

Keywords: peritonsillar abscess, microbiology, aerobe/anaerobe infection

Erdélyi E, Ambrus A, Szabó L, Kiricsi Á, Nagy E, Rovó L, Bella Zs. [The role of microbiological examination in treating peritonsillar abscess based on the retrospective analysis of data from six years]. Orv Hetil. 2020; 161(44): 1877-1883.

(Beérkezett: 2020. április 12.; elfogadva: 2020. május 19.)

\begin{abstract}
Rövidítések
$\mathrm{CRP}=$ C-reaktív protein; EUCAST $=($ European Committee on Antimicrobial Susceptibility Testing) Antimikrobiális Érzékenységi Vizsgálatok Európai Bizottsága; MALDI-TOF MS = (matrix-assisted laser desorption/ionization-time-of-flight mass spectrometry) mátrixasszisztált lézer deszorpciós-ionizációs, a repülési idő mérésén alapuló tömegspektrometria; NSAID $=$ (non-steroidal anti-inflammatory drug) nemszteroid gyulladáscsökkentő gyógyszer; SZTE ÁOK = Szegedi Tudományegyetem, Általános Orvostudományi Kar
\end{abstract}

A peritonsillaris tályog a leggyakoribb mély nyaki infekció $[1,2]$. A mandula körüli tályog a mandulatok és a garatizomzat között helyezkedik el, míg a parapharyngealis tályog az izmoktól laterálisan a garatizmok közötti térségre (spatium parapharyngeum) lokalizálódik. Mindkét folyamat veszélye, hogy a gyulladás a mély nyaki izompólya mentén a mediastinum irányába terjedhet, és a nagy mortalitással járó mediastinitis kialakulásához vezethet. A parapharyngealis lokalizáció gyorsabb terjedést és súlyosabb kórlefolyást mutathat. Amennyiben a peritonsillaris tályogokat nem ismerjük fel és nem kezdjük el kezelni kellő időben, akár fatális kimenetele is lehet a folyamatnak [1-4]. Ezért nagyon fontos, hogy - már a mikrobiológiai tenyésztés eredményének megérkezése előtt - az empirikus antibiotikumválasztás (a szóba jövő kórokozók ismert rezisztenciaviszonyai alapján) optimális legyen. A tályogok kialakulásakor az esetek döntő többségében vegyes, a legtöbbször aerob és anaerob baktériumokat is tartalmazó flóra van jelen, így olyan antibiotikumot vagy antibiotikumkombinációt kell választanunk, amely széles spektrumú, és mind aerob, mind anaerob kórokozók ellen hatékony. Ehhez szükséges a peritonsillaris tályogok tenyésztési eredményeinek elemzése, még ha a mindennapi gyakorlatban nem történik is minden esetben mikrobiológiai tenyésztés. Nem vagy nehezen gyógyuló esetekben újra és újra felmerül a száj és a garatüreg mikrobiomjában megtalálható, nehezen tenyészthető anaerob baktériumok - például Fusobacte- rium necrophorum vagy egyéb fusobacteriumok - kóroki szerepe [3]. Mindemellett természetesen elengedhetetlen a sebészi beavatkozás, a helyi érzéstelenítésben végzett incisio és/vagy tonsillectomia. A beavatkozást, az irodalmi adatok alapján, a beteg általános állapota, illetve életkora befolyásolhatja [2].

Vizsgálatunk célja az volt, hogy áttekintsük a klinikánkon 2012 és 2017 között peritonsillaris tályog miatt kezelt betegek kórtörténetét az alkalmazott sebészi beavatkozás és az empirikusan választott antibiotikumterápia vonatkozásában. Vizsgálataink során értékeltük a peritonsillaris tályoggal kezelt betegek rutin-tályogmintatenyésztésének eredményét, különös tekintettel a ritkán vizsgált anaerob baktériumok előfordulására. Célunk volt továbbá az is, hogy a minél hatékonyabb kezelés érdekében felhívjuk a figyelmet a klinikai gyakorlatban elöforduló esetleges hiányosságokra.

\section{Módszerek}

A retrospektív felmérés során 2012. január l. és 2017. december 31. között az SZTE ÁOK Fül-Orr-Gégészeti és Fej-Nyaksebészeti Klinikáján peritonsillaris tályoggal kezelt betegek kórtörténetét és a mikrobiológiai tenyésztés eredményeit dolgoztuk fel. A parapharyngealis tályoggal diagnosztizált és kezelt betegeket nem vettük be a felmérésünkbe. A vizsgált 6 év alatt 217 beteg klinikai diagnózisa volt peritonsillaris tályog. Az adatgyújtés során kiderült, hogy 24 beteg esetében nem került sor vizsgálati minta átküldésére a mikrobiológiai laboratóriumba tenyésztés céljából, és 17 beteg esetében nem állt rendelkezésre értékelhetô, a tályogminták rutinfeldolgozása során várható tenyésztési eredmény, mert a minta torokváladékként lett átküldve a laboratóriumba, így a laboratóriumi protokoll alapján csak aerob tenyésztés történt. További 30 beteg esetében - feltételezetten a nem megfelelő mintavétel és mintaszállítás vagy a korábban már megkezdett antibiotikumkezelés miatt - mind az aerob, mind az anaerob tenyésztés negatív eredmény- 
nyel zárult. Így a végleges értékelésbe 146 beteget vontunk be.

A klinikán alkalmazott mintavételi protokoll peritonsillaris tályog esetén: incisio során a tályogüregból veszünk tamponnal mintát, a garatfali normálflórával való szenynyeződés kerülése mellett. A minta megfelelő, az aerob és anaerob baktériumok túlélését biztosító transzportközegben kerül beszállításra a laboratóriumba. Sürgősségi („forró”) tonsillectomia esetén a mútét során megnyíló tályogüregbő́l veszünk mintát bakteriológiai tenyésztésre. Mindkét esetben ügyelünk, hogy a mintavétel során szigorúan a tályogüregboól történjen a mintavétel, a szájüregi flórával történő kontamináció nélkül. A kontamináció természetesen nem minden esetben kerülhető el.

A beküldött vizsgálati anyag feldolgozása és értékelése az SZTE ÁOK Klinikai Mikrobiológiai Diagnosztikai Intézete bakteriológiai részlegén történt, a tályogminták tenyésztésére szolgáló, nemzetközileg elfogadott előírások szerint $[5,6]$. A beérkezést követően a minta 3 órán belül feldolgozásra került. Ügyeleti időben sürgősséggel végzett incisio vagy tonsillectomia esetén a tamponnal vett minta transzportközegbe helyezve került tárolásra $+4{ }^{\circ} \mathrm{C}$-on reggelig. Szemikvantitatív leoltás történt aerob és anaerob baktériumok tenyésztésére szolgáló véres, csokoládé és szelektív táptalajokra, valamint aerob és anaerob dúsító folyadékba [5-7]. Az aerob és fakultatív anaerob baktériumok tenyésztésére szolgáló lemezeket 24 óráig $5 \% \mathrm{CO}_{2}$-tartalmú termosztátban, az anaerob baktériumok izolálására szolgáló táptalajokat 48-72 óráig $10 \% \mathrm{H}_{2-}, 10 \% \mathrm{CO}_{2}$ - és $80 \% \mathrm{~N}_{2}$-tartalmú atmoszférában, anaerob 'chamberben' (Concept Plus; LAFtech Ruskinn Technology USA) inkubáltuk. Az izolált törzsek azonosítása MALDI-TOF MS (matrix-assisted laser desorption/ionization-time-of-flight mass spectrometry) módszerrel történt (Bruker Daltonics GmbH, Bréma, Németország) [8-10]. A speciesszintú azonosítást a gyártó elóírása alapján akkor fogadtuk el, ha a $\log$ (score) értéke $\geq 2.000$ volt. Az aerob és fakultatív anaerob baktériumok antibiotikumérzékenységének meghatározását a laboratórium az EUCAST-irányelvek alapján korongdiffúziós módszerrel végezte [11]. Az anaerob baktériumok esetében a terápiás ajánlás a nemzetközi és a hazai rezisztenciafelmérések alapján történt $[5-7,12]$.

\section{Eredmények}

Vizsgálatunk során a betegek között férfidominancia volt észlelhető (84 férfi és 62 nő). A peritonsillaris tályog 15 és 40 év között fordult elő a leggyakrabban (85 eset), kevés volt a 14 év alatti korcsoportba tartozó beteg (9 eset), és 52 eset a 40 év feletti korcsoportba tartozott. A legfiatalabb beteg 6 éves, a legidősebb 75 éves volt, az átlagéletkor 34,66 évnek adódott. Minden esetben történt sebészi beavatkozás. Az első lépésben 111 betegnél végeztünk helyi érzéstelenítésben incisiót, melyet 23 esetben 1-3 napon belül „korai” tonsillectomiával egészítettünk ki, amennyiben a beteg állapota a megnyitás és
1. táblázat A sebészi beavatkozás és a tenyésztési eredmények összehasonlítása a 146, peritonsillaris tályog miatt kezelt beteg esetében

\begin{tabular}{lccc}
\hline Beavatkozás és mintavétel & \multicolumn{3}{c}{ Esetszám } \\
\cline { 2 - 4 } & Összesen & $\begin{array}{c}\text { Egyetlen } \\
\text { kórokozó } \\
\text { tenyészett }(48)\end{array}$ & $\begin{array}{c}\text { Vegyes } \\
\text { baktériumflóra } \\
\text { tenyészett }(98)\end{array}$ \\
\hline Incisio* & 111 & $33(68,8 \%)$ & $78(79,6 \%)$ \\
Csak incisio történt & 43 & 13 & 30 \\
$\begin{array}{l}\text { Incisio + „korai” } \\
\text { tonsillectomia }\end{array}$ & 23 & 5 & 18 \\
$\begin{array}{l}\text { Incisio + „halasztott” } \\
\text { tonsillectomia }\end{array}$ & 45 & 15 & 30 \\
„Forró” tonsillectomia* * & 35 & $14(29,2 \%)$ & $21(21,4 \%)$ \\
\hline
\end{tabular}

*A mintavétel minden esetben az incisio során közvetlenül a tályogbennékből történt a garati kontamináció elkerülésével.

**A mútét során megnyíló tályogüregből történt a mintavétel.

a parenteralisan adott empirikus antibiotikumkezelés ellenére sem javult kelló mértékben (1. táblázat). Ezen betegek közül 18 esetben észleltünk polimikrobiális fertőzést, és 5 betegnél egyetlen aerob vagy anaerob baktériumot izolált a laboratórium. További 45 beteg esetében a későbbiekben az empirikus, illetve célzott antibiotikumterápiát és a gyulladásos tünetek teljes megszűnését követően „halasztott” tonsillectomiát végeztünk a recidívák elkerülése érdekében. Ezen betegek esetében is dominált azok száma, akiknél a tályogmintából vegyes baktériumflórát izolált a laboratórium $(32$ versus 13). Azon betegeknél, akik a helyi érzéstelenítésben végzendő incisiót nem vállalták, vagy a nagyfokú szájzár, illetve a rossz általános állapot miatt az nem volt kivitelezhető ( 26 beteg), illetve gyermekek esetében (9 beteg) azonnali mandulaeltávolítást („forró” tonsillectomia) hajtottunk végre intratrachealis narkózisban (1. táblázat). A sebészi beavatkozás, illetve a mintavétel módja nem befolyásolta a tenyésztési eredményt, a tályogminták kétharmada (98/146) vegyes baktériumflórát eredményezett (1. táblázat).

A sebészi kezelés mellett az összes betegünk empirikus intravénás antibiotikumterápiában részesült. A leggyakrabban amoxicillin-klavulánsavat alkalmaztunk monoterápiában 63 betegnél, illetve metronidazollal kombinálva további 34 páciensnél. A második leggyakrabban alkalmazott antibiotikumcsoportot a 2 . és 3 . generációs cefalosporinok jelentették. Összesen 38 esetben monoterápiában, 9 esetben metronidazollal, 1 esetben pedig klindamicinnel kombinálva alkalmaztuk (2. táblázat). Két esetben volt szükség terápiaváltásra. Az egyik esetben polimikrobiális fertőzés volt észlelhető, és az első lépésben csak incisióra került sor, majd „korai” tonsillectomiát végeztünk, itt cefuroximról amoxicillin-klavulánsavra váltottunk. A másik betegünk esetében monobakteriális fertőzés volt (Streptococcus pyogenes), itt azonban a megkezdett amoxicillin-klavulánsav-kezelés és az incisio mellett a beteg panaszai progrediáltak, ezért a 3. napon cefuroxim-metronidazol-kombinációra váltottunk, és el- 
A 146 , peritonsillaris tályog miatt kezelt beteg megoszlása az empirikusan alkalmazott mono- vagy kombinált antibiotikumte rápia alapján

\begin{tabular}{lc}
\hline Empirikus terápia & $\begin{array}{c}\text { A betegek } \\
\text { száma }(\%)\end{array}$ \\
\hline Monoterápiában részesült & $102(100 \%)^{*}$ \\
Amoxicillin-klavulánsav & $63(61,8 \%)$ \\
2. vagy 3. generációs cefalosporin & $38(37,3 \%)$ \\
Ciprofloxacin & $1(0,98 \%)$ \\
Kombinált terápiában részesült & $44(100 \%)^{*}$ \\
Amoxicillin-klavulánsav + metronidazol & $34(77,3 \%)$ \\
2. vagy 3. generációs cefalosporin + metronidazol & $9(20,5 \%)$ \\
2. vagy 3. generációs cefalosporin + klindamicin & $1(2,3 \%)$ \\
\hline
\end{tabular}

*A 102 beteget vesszük 100\%-nak, így tudjuk ehhez viszonyítani a monoterápia \%-os eloszlását.

**A 44 beteget vesszük 100\%-nak, így tudjuk ehhez viszonyítani a kombinált terápia \%-os eloszlását.

végeztük a tonsillectomiát; a beteget a 7 . napon per os antibiotikumterápiával bocsátottuk otthonába.

A betegek a bennfekvés során 2-15 napig parenteralis, majd otthonukban további 5-7 napig per os antibiotikumterápiát (amoxicillin-klavulánsav, cefuroxim, metronidazol, klindamicin) kaptak, annak megfelelően, hogy a hospitalizációjuk alatt milyen parenteralis antibiotikumkezelésben részesültek. A kórházi kezelés átlagos időtartama 4,5 nap volt. A „forró” tonsillectomiával kiegészített kezelés nem változtatta meg a hospitalizáció időtartamát, de az otthoni lábadozást egy héttel meghosszabbította (összességében átlagosan 2 hét). A hoszszabb gyógyulási idő a mandulaeltávolítás okozta nagyobb sebfelszín hosszabb gyógyulási idejével magyarázható, a lényegesen kisebb mértékű incisióhoz viszonyítva. Ez megegyezik az átlagos tonsillectomiát követő gyógyulási idővel. A megfelelő kezelés után minden betegünk gyógyultnak volt tekinthető. Mindössze 3 betegnél kellett tracheotomiát végezni a nagyfokú gyulladás, valamint a légutat is veszélyeztető gyulladás körüli oedema miatt; ők a mútéti beavatkozás után posztoperatív megfigyelés céljából pár napos intenzív osztályos kezelést igényeltek, majd osztályunkon kezeltük óket tovább. A tracheotomizált betegek közül 1 betegnek kezelt diabetese volt, 1 betegnél fulmináns lefolyású volt a polimikrobiális fertőzés, 1 beteg pedig igen későn, előrehaladott állapotban érkezett klinikánkra. Egyéb szövődmény, funkcióvesztés vagy tartós további ápolási igény nem jelentkezett. A tonsillectomián átesett betegek ( „forró”, incisio utáni „forró” vagy „halasztott” tonsillectomia) 2 héten belül meggyógyultak súlyosabb szövődmény nélkül. Azok a betegek, akiknél csak bemetszést végeztünk, hamarabb, egy héten belül panaszmentessé váltak, és visszatérhettek a közösségbe. Mortalitást a jelen feldolgozott beteganyagban nem észleltünk. Ezen tanulmányban a nagyobb mortalitási kockázattal jellemezhető parapharyngealis, illetve retropharyngealis
3. táblázat A tályogminták mikrobiológiai tenyésztéses vizsgálatának eredménye

\begin{tabular}{lc}
\hline A tenyésztés eredménye & Esetszám (százalék) \\
\hline $\begin{array}{l}\text { Egyetlen baktérium/gomba tenyészett (48) } \\
\text { (monobakteriális tályog) }\end{array}$ & \\
Nyálflóra kis csíraszámban & $15(31,3)$ \\
Aerob baktérium & $23(47,9)$ \\
Anaerob baktérium & $10(20,8)$ \\
Sarjadzó gomba & $1(2,1)$ \\
2-8 baktérium/gomba tenyészett (98) & \\
(polimikrobiális tályog) & \\
Nyálflóra kis csíraszámban & $15(15,3)$ \\
Csak aerob baktérium & $3(3,0)$ \\
Csak anaerob baktérium & $47(47,9)$ \\
Aerob és anaerob baktérium & $29(29,6)$ \\
+ Sarjadzó gomba & $4(4,1)$ \\
\hline
\end{tabular}

tályoggal szövődött eseteket nem dolgoztuk fel, csak az izolált peritonsillaris tályogos eseteket.

A mikrobiológiai vizsgálatok eredményei alapján 48 beteg tályogmintájából egyetlen baktérium, illetve sarjadzó gomba tenyészett ki. Ezek közül 15 betegnél $(31,3 \%)$ csak alacsony csíraszámban, a normálnyálflórában is megtalálható aerob vagy anaerob baktériumot igazolt a laboratórium, I esetben ugyancsak alacsony csíraszámban sarjadzó gomba tenyészett (3. táblázat). A monobakteriális tályogmintákban a kórokozónak tekinthető aerob baktériumok dominanciája érvényesült (az esetek 47,9\%-a), míg anaerob baktérium mindössze 10 esetben $(20,8 \%)$ volt jelen a mintában. 5 esetben Fusobacterium necrophorumot és 2 esetben Actinomyces odontolyticust izolált a laboratórium mint egyedüli kórokozót (3. és 4. táblázat). Azon tályogminták esetében, amikor 2-8 baktérium izolálására került sor a beküldött mintából (98 beteg), szintén jelentős számban fordultak elő olyan tályogminták (15 eset; 15,3\%), amelyeknél alacsony csíraszámban (2-3 izolátum), a normálnyálflóra tagjainak tartható, aerob és/vagy anaerob baktériumot izolált a laboratórium, sokszor csak a dúsító folyadékból. Kórokozónak tartható, csak aerob baktériumokat tartalmazó tályogmintát az esetek 3\%-ában találtunk. Az anaerob speciesek jelentősen nagyobb számban kerültek izolálásra a polimikrobiális tályogok esetében: így csak anaerob baktériumokat a polimikrobiális tályogminták 47,9\%-ában izolált a laboratórium, és az esetek 29,6\%ában vegyes aerob/anaerob flóra tenyészett. Mindössze 4 olyan beteg volt, akinél a vegyes baktériumflóra mellett sarjadzó gomba izolálására is sor került alacsony csíraszámban (3. táblázat).

A 4. táblázatban a leggyakoribb, patogénnek tartott aerob és anaerob speciesek előfordulását tüntettük fel a monobakteriális és a polimikrobiális tályogos betegek esetében. A monobakteriálistályog-mintákban a leggyakoribb aerobpatogén-izolátum a Streptococcus pyogenes (11 beteg) és a C- vagy G-csoportba tartozó Streptococ- 
4. táblázat A leggyakoribb kórokozónak tartott baktériumok előfordulása monobakteriális és a polimikrobiális tályoggal kezelt betegek tályogmintájában

\begin{tabular}{lcc}
\hline Speciesek & \multicolumn{2}{c}{ Az esetek száma } \\
\cline { 2 - 3 } & $\begin{array}{c}\text { Monobakteriális } \\
(48)\end{array}$ & $\begin{array}{c}\text { Polimikrobiális } \\
(98)\end{array}$ \\
\hline Aerob baktériumok & 11 & 18 \\
Streptococcus pyogenes & 2 & 2 \\
Streptococcus C- és G-csoport & 2 & 2 \\
Streptococcus pneumoniae & 1 & 6 \\
Staphylococcus aureus & 0 & 4 \\
Haemophilus influenzae & & \\
Anaerob baktériumok & 5 & 20 \\
Fusobacterium necrophorum & 0 & 13 \\
Fusobacterium nucleatum & 0 & 9 \\
Fusobacterium spp. & 0 & 47 \\
Prevotella spp. & 0 & 4 \\
Porphyromonas spp. & 2 & 16 \\
Actinomyces odontolyticus & 0 & 13 \\
Actinomyces spp. & &
\end{tabular}

spp. = species

cus ( 2 beteg) volt. 5 esetben az anaerob speciesek közé tartozó Fusobacterium necrophorumot és 2 esetben Actinomyces odontolyticust igazolt a laboratórium. 1, Staphylococcus aureus és 2, Streptococcus pneumoniae okozta monobakteriális tályogot találtunk (4. táblázat). A polimikrobiálistályog-mintákban az izolált baktériumok száma 2 és 8 között mozgott; sok esetben csak anaerob tenyésztési körülmények között telepet képező baktérium volt igazolható, illetve sok esetben vegyes, aerob- és anaerobbaktérium-populáció tenyészett. A leggyakoribb patogén aerob baktérium ebben az esetben is a Streptococcus pyogenes volt (18 beteg) néhány egyéb, a felső légutakban elóforduló aerob patogén baktérium előfordulása mellett (4. táblázat). Az anaerob izolátumok közül 42 beteg $(42,9 \%)$ esetében volt igazolható valamelyik Fusobacterium species, és ezek közül a leggyakrabban (20 beteg) a Fusobacterium necrophorum jelenléte volt igazolható nagy csíraszámban, egyéb aerob és anaerob baktériumok mellett. Nagyszámú beteg tályogmintájában az oralis mikrobiomban előforduló Prevotella, illetve Porphyromonas speciesek voltak megtalálhatók nagy csíraszámban. Összesen 16 beteg esetében került izolálásra Actinomyces odontolyticus, illetve 13 esetben egyéb Actinomyces species (4. táblázat).

\section{Megbeszélés}

Statisztikai adatok szerint az orvoshoz fordulás leggyakoribb oka mind felnőtt-, mind gyermekkorban a felső légúti infekció. A heveny tonsillopharyngitis felnőttkorban 90\%-ban, gyermekkorban 70\%-ban virális eredetü. A vezető bakteriális kórokozó a Streptococcus pyogenes, de az utóbbi években számos közlemény hívja fel a figyelmet a nehezen tenyészthetó és identifikálható anaerob baktérium, a Fusobacterium necrophorum esetleges kóroki szerepére is fiatal felnőttek tonsillopharyngitise esetében $[13,14]$. A bakteriális eredet alátámasztására a vérkép (balra tolt, leukocytosis), a CRP-emelkedés és az antigénkimutató „rapid strep test” igazolhatja a leggyakoribb, A-csoportú Streptococcus kórokozó szerepét. Az elsődleges terápiaválasztásnál ezt kell figyelembe venni, tehát penicillin, amoxicillin-klavulánsav vagy 2 . generációs cefalosporin választandó. Egyéb baktériumok - például Staphylococcus aureus, Haemophilus influenzae nem kórokozók a garatban, hanem hordozott mikrobák, tehát nem erre választunk terápiát. A Streptococcus pyogenes okozta tonsillopharyngitis elleni terápia hatástalansága esetén, különösen, ha rekurrens infekció észlelhető, érdemes a szokásos aerob tenyésztés mellett az anaerob Fusobacterium necrophorum jelenlétének igazolását is megkísérelni [14].

Ha a gyulladás tovább terjed a tonsilla kötőszövetes tokján, és a mandula körüli szöveteket is érinti, akkor peritonsillitis alakul ki, általában féloldali duzzanattal, garatív-aszimmetriával. Ez a gyulladás már lezárt anaerob környezetben jön létre, és az anaerob kórokozók jelenlétével is számolnunk kell. Ha gennyképződés még nincs, érdemes az eredeti, empirikusan választott antibiotikumterápiát kiegészíteni kifejezetten anaerob baktériumok ellen hatásos szerrel, mütéti teendő még nem szükséges. Az antibiotikum választásakor a széles spektrumú, anaerobokra is ható gyógyszerek javasolhatók: béta-laktám/béta-laktamáz gátló, például amoxicillinklavulánsav vagy piperacillin-tazobaktám, melyet kiegészíthetünk metronidazollal. A 2., illetve 3. generációs cefalosporinok adása csak kombinációban javasolt klindamicinnel vagy metronidazollal az anaerob baktériumokra való nem megfelelő hatásuk miatt. A szöveti penetráció javítása érdekében a parenteralis alkalmazás hatékonyabb. A tonsillatok és a parapharyngealis izomzat között létrejövő gennygyülem tályogüreget képez. A tonsillát és a garatívet tovább előemelve garati aszimmetria jön létre, spatulával tapintva fluktuáció észlelhető. A beteg beszéde galuskássá válik, a nyelés nehezített, előrehaladott esetben szájzár, korlátozott szájnyitás jelentkezik. A körülírt letokolt folyamat retropharyngealisan és parapharyngealisan is terjedhet, ami az izmokat körülvevő kötőszöveti lemezek alkotta rés mentén gyors lefelé terjedést idézhet elő (phlegmone), és mediastinitis kialakulását okozhatja, mely életveszélyes szövődményt jelent. Letalitása akár az 50\%-ot is elérheti [15]. A tályogképződés a parenteralis antibiotikum adása mellett sebészi beavatkozást igényel. A peritonsillaris térben letokolt genny a felsô pólus és a hilus (középső harmad) területéról incisio során lebocsátható. Gyakran a kisebb invazivitással járó, ambulánsan is elvégezhető punkciót preferálják, amely alkalmas a gennygyülem igazolására és mintavételre a garatflórával történő kontamináció nélkül [15]. A retrotonsillaris vagy alsó harmadi, illetve a para- 
pharyngealis térbe terjedő folyamat esetén a drenázs a mandula teljes eltávolításával biztosítható. A sebészi terápia elsődleges célja a gennygyülem lebocsátása és az anaerob közeg megszüntetése, de ez utóbbira a punkció nem minden esetben elégséges. Tonsillectomia esetén törekszünk az ellenoldali mandula eltávolítására is. Kivételt képez a rossz általános állapot, az előrehaladott stádiumú infekció (például szepszis, mediastinitis) és különösen a vérzékenység (májbetegség, antikoaguláns terápia stb.). A megfelelően választott antibiotikumterápia a gyulladásos folyamat előrehaladását és további szövődmények (thrombophlebitis, távoli tályogképződés) kialakulását akadályozhatja meg. Az optimális terápiaválasztás, illetve -megerósítés (célzott antibiotikumterápia) a mikrobiológiai tenyésztésen alapul.

A punkció vagy incisio, illetve a tonsillectomia során minden esetben ajánlott a mintavétel mikrobiológiai tenyésztés céljából, lehetőség szerint még az empirikus antibiotikumterápia megkezdése előtt. A mikrobiológiai mintavétel jelentősége az is, hogy jobban megismerjük a szájüregi mikrobiom szerepét az egyes betegségek, így a peritonsillaris tályog kialakulásában [16]. A Streptococcus pyogenes mellett a Fusobacterium necrophorum vagy más anaerob baktériumok patogén szerepét a tonsillitis mellett a fiatal felnőttkori peritonsillaris tályogok esetében is igazolták [17-19]. A jelen felmérésben, tudomásunk szerint elsőként Magyarországon, a monobakteriális peritonsillaris tályogos betegek 10,4\%-ánál találtunk Fusobacterium necrophorumot mint egyetlen patogént. Azon betegek esetében, akiknél tenyésztéssel polimikrobiális tályogot igazoltunk, a betegek 20,4\%-ánál volt jelen a Fusobacterium necrophorum a mintában . Ez a megfelelő tenyésztési eljárásokon alapuló, más centrumokban végzett retrospektív felmérésekhez hasonló adatokat mutat. Ali és mtsai [18] a peritonsillaris tályogok 31\%-ában, míg Klug és mtsai [3] az izolált törzsek 41\%-ában igazolta a Fusobacterium necrophorum jelenlétét. Azon 23 esetben, amelynél az incisiót „forró” tonsillectomiával kellett kiegészíteni, 10 betegnél $(43,5 \%)$ tudtunk Fusobacterium necrophorumot kimutatni. Ezen esetek 78,3\%-ában polimikrobiális fertózést észleltünk. A jelentős anaerob jelenlét okozhatja, hogy a betegek állapota nem javul kellő mértékben incisio hatására.

A Fusobacterium necrophorum korábban leginkább mint a Lemierre-szindróma kórokozója került szóba. A Lemierre-szindróma a vena jugularis thrombophlebitisével és esetenként szeptikus embolisatióval jár, amely súlyos, akár életet veszélyeztető és maradandó károsodást okozó kórkép. Az általunk vizsgált betegpopulációban a Lemierre-szindróma gyanúja nem merült fel.

A legtöbb tanulmány szerint az Actinomyces speciesek kóroki szerepe a garatmandula-túltengésben, illetve a nyirokszövet hyperplasiájában igazolható [20]. Jelen vizsgálatunkban a 146 peritonsillaris tályogból 31 esetben izoláltunk Actinomyces odontolyticust vagy egyéb Actinomyces speciest. Az irodalmi adatok alapján az Actinomyces speciesek a nyálkahártya-barriert károsíthatják, így maguk is invazív kórokozóvá válhatnak, valamint behatolási kaput nyithatnak más kórokozóknak, amelyek a peritonsillaris tályogok kialakulásában szerepet játszanak [21].

A peritonsillaris tályogból történő mintavétel számos hibalehetőséget hordoz. A szájflórával való kontamináció kerülendő. Javasolt a tályoggyanús esetben punkcióval identifikálni a tályogüreget, aspirációval zárt steril fecskendőbe mintát venni és az incisiót ezután elvégezni [17]. A fecskendóből a minta az anaerob transzporttáptalajra fecskendezhető, és pontos azonosítókkal ellátva, „tályogbennék” felirattal 2 órán belül a mikrobiológiai laboratóriumba kell juttatni. Hosszú ideig történő, hütőszekrényben való mintatárolás nem javasolt. A kérólap kitöltése legyen pontos, az aerob + anaerob + gomba irányú tenyésztés igényét jelezni kell. Ha a 'tályog' megjelölés nem szerepel a kérőlapon, esetleg torokváladékként érkezik a minta, a mikrobiológiai laboratórium nem végez anaerob leoltást! Az alapprotokolltól való eltérést (protokolldeviáció) írásban vagy szóban a mikrobiológiai laboratóriummal egyeztetni kell. A megfelelö protokoll betartása lehetőséget nyújt, hogy az empirikusan választott antibiotikumterápia a korrekt tenyésztési eredmények birtokában célzottá tehető legyen. A laboratóriumnak rendelkeznie kell megfelelő anaerob tenyésztést biztosító berendezéssel és a tályogmintából izolált valamennyi baktérium speciesszinten történő azonosítására alkalmas eljárással. További tervezett vizsgálatok mutathatnak rá a polimikrobiálistályog-flóra egyes tagjainak patogén szerepére az egyes nehezen gyógyuló esetekben.

\section{Következtetés}

A mikrobiomkutatásnak egyre nagyobb jelentősége van a fül-orr-gégészeti kórképek jobb megértésében és az ok-okozati összefüggések feltárásában is. A szájüregi mikrobiomban nagy számban megtalálhatók nehezen tenyészthető anaerob baktériumok. Infekciós kórképekben való szerepük mellett egyes betegségekre való hajlamban, rákmegelőzó állapotok kialakulásában, illetve tumoros megbetegedések bakteriális hátterének igazolásában is felmerül a szerepük $[16,19]$. A tályogképződést szisztémás és helyi viszonyok segíthetik elő. A rossz szájhigiéné, a dohányzás, a diabetes mellitus és az immunhiányos vagy immunszupprimált állapotok biztosan hajlamosító tényezők egy-egy fül-orr-gégészeti kórkép kialakulásában. Az elhúzódó NSAID-kezelés vagy a nem megfelelően választott vagy túl rövid ideig alkalmazott antibiotikumterápia is gyakran szerepel az anamnézisben. De a peritonsillaris tályogok szinte kizárólagosan egyoldali megjelenése a lokális okok szerepét erősítik. A gyakori tonsillopharyngitisek, heges tonsillák, korábbi mútét utáni heges tonsillacsonk (hegtályog) a lokális keringést rontják, a lokális immunfolyamatok effektivitása csökken. A heges környezetben preformált üregek keletkezhetnek, anaerob környezet alakulhat ki, mely a szájüreg mikrobiomjában bőségesen megtalálható anaerob baktériumok elszaporodását segítik elő [16]. Konzerva- 
tív vagy kevésbé invazív terápiát (punkció, incisio) és gyógyulást követően javasolt a "halasztott” tonsillectomia későbbi időben történő elvégzése. Ennek hiányában a lokális gyulladások és recidiváló tályogok előfordulásának aránya nagy [15]. Mindezek ismeretében sokan, ha a beteg általános állapota ezt lehetôvé teszi, a tályogos mandula primer („forró”) eltávolítását javasolják megfelelő, széles spektrumú antibiotikum alkalmazása mellett $[4,22]$, figyelembe véve a klinikai antibiotikumkutatás legújabb eredményeit [23-27].

Anyagi támogatás: A jelen közlemény megírása és az adatgyüjtés során anyagi támogatásban egy szerző sem részesült.

Szerzői munkamegosztás: E. E.: Adatgyưjtés, elemzés, a közlemény megírása. A. A., Sz. L.: Irodalomkutatás. N. E.: Az eredmények elemzése, a következtetések megfogalmazása, mikrobiológiai véleményezés. K. Á., R. L.: Tudományos értékelés. B. Zs.: A tanulmány vezetője, részvétel a közlemény megírásában, a következtetések megfogalmazásában. A cikk végleges változatát valamennyi szerző elolvasta és jóváhagyta.

Érdekeltségek: A szerzők szakmai fejlődése és a mindennapi gyakorlatban használatos protokollok áttekintése mikrobiológiai szempontok szerint. A szerzőknek egyéb érdekeltsége nincs.

\section{Irodalom}

[1] Lepelletier D, Pinaud V, Le Conte P, et al. Peritonsillar abscess (PTA): clinical characteristics, microbiology, drug exposures and outcomes of a large multicenter cohort survey of 412 patients hospitalized in 13 French university hospitals. Eur J Clin Microbiol Infect Dis. 2016; 35: 867-873.

[2] Herzon FS. Peritonsillar abscess: incidence, current management practices, and a proposal for treatment guidelines. Laryngoscope 1995; 105 (Suppl 3): 1-17.

[3] Klug TE, Rusan M, Fuursted K, et al. Fusobacterium necrophorum: most prevalent pathogen in peritonsillar abscess in Denmark. Clin Infect Dis. 2009; 49: 1467-1472.

[4] Buckley J, Harris AS, Addams-Williams J. Ten years of deep neck space abscesses. J Laryngol Otol. 2019; 133: 324-328.

[5] Carroll KC, Pfaller MA, Landry ML, et al. Manual of clinical microbiology, 2 Volume Set. 12th Edition. ASM Press, Washington, DC, 2019.

[6] Jousimies-Somer HR, Summanen P, Citron DM, et al. Wadsworth Anaerobic Bacteriology Manual (6th edn). Star Publishing Company, Belmont, CA, 2002.

[7] Nagy E, Boyanova L, Justesen US. How to isolate, identify and determine antimicrobial susceptibility of anaerobic bacteria in routine laboratories. Clin Microbiol Infect. 2018; 24: 11391148.

[8] Patel R. Matrix-assisted laser desorption ionization-time of flight mass spectrometry in clinical microbiology. Clin Infect Dis. 2013; 57: 564-572.

[9] Nagy E, Maier T, Urban E, et al. Species identification of clinical isolates of Bacteroides by matrix-assisted laser-desorption/ionization time-of-flight mass spectrometry. Clin Microbiol Infect. 2009; 15: 796-802
[10] Kostrzewa M, Nagy E, Schröttner P, et al. How MALDI-TOF mass spectrometry can aid the diagnosis of hard-to-identify pathogenic bacteria - the rare and the unknown. Expert Rev Mol Diagn. 2019; 19: 667-682.

[11] The European Committee on Antimicrobial Susceptibility Testing. Breakpoint tables for interpretation of MICs and zone diameters. Version 7.1, 2017. Available from: http://www.euc.ast. org [accessed: April 10, 2020].

[12] Nagy E, Urbán E, Nord CE. Antimicrobial susceptibility of Bacteroides fragilis group isolates in Europe: 20 years of experience. Clin Microbiol Infect. 2011; 17: 371-379.

[13] Jensen A, Hansen TM, Bank S, et al. Fusobacterium necrophorum tonsillitis: an important cause of tonsillitis in adolescents and young adults. Clin Microbiol Infect. 2015; 21: 266.el.-266.e3.

[14] Holm K, Bank S, Nielsen H, et al. The role of Fusobacterium necrophorum in pharyngotonsillitis - a review. Anaerobe 2016; 42: 89-97.

[15] Galioto NJ. Peritonsillar abscess. Am Fam Physician 2017; 95: 501-506.

[16] Fekete Sz, Szabó D, Tamás L, et al. The role of the microbiome in otorhinolaryngology. [A mikrobiom szerepe a fül-orrgégészetben.] Orv Hetil. 2019; 160: 1533-1541. [Hungarian]

[17] Gavriel H, Lazarovitch T, Pomortsev A, et al. Variations in the microbiology of peritonsillar abscess. Eur J Clin Microbiol Infect Dis. $2009 ; 28$ : 27-31.

[18] Ali SA, Kovatch KJ, Smith J, et al. Implication of Fusobacterium necrophorum in recurrence of peritonsillar abscess. Laryngoscope 2019; 129: 1567-1571.

[19] Yusuf E, Wybo I, Piérard D. Case series of patients with Fusobacterium nucleatum bacteremia with emphasis on the presence of cancer. Anaerobe 2016; 39: 1-3.

[20] Kutluhan A, Salviz M, Yalçiner G, et al. The role of the actinomyces in obstructive tonsillar hypertrophy and recurrent tonsillitis in pediatric population. Int J Pediatr Otorhinolaryngol. 2011; 75: 391-394.

[21] Daneshmandan N. Prevalence of tonsillar actinomycosis in tonsillectomy specimens. Clinical importance and management. J Pediatr Res. 2019; 6: 135-140.

[22] Albertz N, Nazar G. Peritonsillar abscess: treatment with immediate tonsillectomy -10 years of experience. Acta Otolaryngol. 2012; 132: 1102-1107.

[23] Laub K, Tóthpál A, Kovács E, et al. High prevalence of Staphylococcus aureus nasal carriage among children in Szolnok, Hungary. Acta Microbiol Immunol Hung. 2018; 65: 59-72.

[24] Hesari MR, Salehzadeh A, Darsanaki RK. Prevalence and molecular typing of methicillin-resistant Staphylococcus aureus carrying Panton-Valentine leukocidin gene. Acta Microbiol Immunol Hung. 2018; 65: 93-106.

[25] Šmitran A, Vuković D, Opavski N, et al. Influence of subinhibitory antibiotic concentration on Streptococcus pyogenes adherence and biofilm production. Acta Microbiol Immunol Hung. 2018; 65: $229-240$

[26] Khoshnood S, Shahi F, Jomehzadeh N, et al. Distribution of genes encoding resistance to macrolides, lincosamides, and streptogramins among methicillin-resistant Staphylococcus aureus strains isolated from burn patients. Acta Microbiol Immunol Hung. 2019; 66: 387-398.

[27] Manilal A, Shewangizaw M, Mama M, et al. Methicillin-resistant Staphylococcus aureus colonization in HIV patients of Arba Minch province, Ethiopia: carriage rates, antibiotic resistance, and biofilm formation. Acta Microbiol Immunol Hung. 2019; 66: 469-483.

(Erdélyi Eszter dr., Szeged, Tisza Lajos krt. 111., 6725 e-mail: eszter.erdelyi123@gmail.com)

A cikk a Creative Commons Attribution 4.0 International License (https://creativecommons.org/licenses/by/4.0/) feltételei szerint publikált Open Access közlemény. (SID_1) 